\title{
MENINGKATKAN KUALITAS PEMASARAN HOME INDUSTRYTAPE KETAN DI DESA HEULEUT KECAMATAN KADIPATEN KABUPATEN MAJALENGKA
}

\author{
R. Neny Kusumadewi, Nita Hernita, Melia Wida Rahmayani \\ Fakultas Ekonomika dan Bisnis Universitas Majalengka, Indonesia \\ kusumadewi.neny@gmail.com.
}

\begin{abstract}
Heuleut Village, Kadipaten Subdistrict has quite good potential for MSMEs, one of which is a mainstay product is the home industry for tape products, and with the existence of these MSMES as a source of income in Heuleut Village. But on the other hand, these MSMEs have not yet focused and focused on economic development in Heuleut Village, especially for tape products, so that business development is often constrained by several things. SMEs have the potential to develop a business, but there are several problems, including: limited raw materials, sticky tape packaging is still not optimal, marketing is still carried out by going around Heuleut Village and making sticky rice tape is still done manually (Home Industy). Through Community Service which is carried out by providing socialization and education on marketing management, packaging and providing links to the supply of raw materials, Heuleut Village UKM players can find solutions related to existing problems.
\end{abstract}

Keyword : Quality Marketing, Heuleut Village, SME

\begin{abstract}
Abstrak
Desa Heuleut Kecamatan Kadipaten memiliki potensi UMKM yang cukup baik salah satunya menjadi produk andalan adalah home industry produk tape, dan dengan adanya UMKM tersebut sebagai salah satu sumber penghasilan di Desa Heuleut. Namun disisi lain UMKM tersebut belum mengarah dan fokus pada pengembangan ekonomi di Desa Heuleut khususnya untuk produk tape, sehingga dalam pengembangan usaha sering terkendala oleh beberapa hal. Para pelaku UKM berpotensi untuk mengembangkan usaha, namun terdapat beberapa permasalahan antara lain : terbatasnya bahan baku, pengemasan tape ketan masih belum maksimal, pemasaran masih dilakukan dengan cara berkeliling di Desa Heuleut dan untuk pembuatan tape ketan masih di lakukan secara manual (Home Industy). Melalui Pengabdian Kepada Masyarakat yang dilaksanakan dengan memberikan sosialisasi dan edukasi pengelolaan pemasaran, packaging dan pemberian link penyediaan bahan baku, maka pelaku UKM Desa Heuleut dapat dicarikan solusi terkait permasalahan yang ada.
\end{abstract}

Kata Kunci : Kualitas Pemasaran, Desa Heuleut, UKM

\begin{tabular}{l|l|l} 
Submitted: $2020-09-14$ & Revised: $2020-10-06$ & Accepted: 2020-10-09
\end{tabular}

\section{Pendahuluan}

Usaha Kecil dan Menengah (UKM) di bidang kuliner memiliki pesona yang hebat saat ini, Hal ini dapat memberikan kontribusi bagi pertumbuhan ekonomi bagi masyarakat. Persaingan dagang di era modern ini memunculkan spekulasi untuk mampu bertahan dan mampu bersaing dengan industri lainya. Kabupaten Majalengka menjadi salah satu wilayah yang memiliki beragam industri, dengan kehadiran Bandara Internasional Jawa Barat dan pembangunan Tol Cipali menjadikan Majalengka lebih strategis dan dijadikan sebagai sasaran dan target para investor untuk membuka usaha. Penduduk lokal harus mampu bersaing supaya dapat bertahan hidup dan tidak tergerus oleh industri yang lebih besar. Dengan diberlakukan Undang-Undang nomor 6 tahun 2014 tentang Desa maka 
menjadi peluang yang sangat besar bagi setiap desa yang ada di Indonesia untuk bisa mengembangakan setiap potensi yang dimilikinya secara mandiri sesuai kebutuhan masing-masing dalam rangka mewujudkan kesejahteraan masyarakat. Pengaturan desa antara lain bertujuan mendorong prakarsa, gerakan, dan partisipasi masyarakat Desa untuk pengembangan potensi dan Aset Desa guna kesejahteraan bersama; serta, memajukan perekonomian masyarakat Desa serta mengatasi kesenjangan pembangunan nasional; (UU nomor 6 th 2014 pasal 4). Saat ini masih sangat sedikit desa yang mampu mengembangkan potensi ekonominya. Hal ini disebabkan selama ini desa lebih banyak diposisikan sebagai obyek pembangunan sehingga sangat menggantungkan diri pada bantuan pemerintah pusat. Rendahnya kreatifitas sumber daya manusia di desa sebagai akibat dari system pembangunan yang bersifat sentralistik pada masa lalu mengakibatkan banyak potensi dibiarkan terbengkalai tidak dikembangkan untuk sumber kemakmuran masyarakat. Saatnya kita membangun desa yang berbasis pada potensi desa yang dimiliki. Saat ini UKM-UKM yang memproduksi makanan sangat membutuhkan peningkatan kualiats produk, peningkatan kapasitas serta perluasan pemasaran produk (Muhamad Firdaus, dkk, 2018).

Pemasaran merupakan kunci kesuksesan suatu usaha, baik bidang jasa maupun produk. Di era modernisasi, pemasaran juga tidak dapat hanya dilakukan secara konvensional dengan melakukan pemasaran di lapangan saja, akan tetapi kita juga harus mulai menggunakan pemasaran modern dengan berbasis online, sehingga dapat meningkatkan kualitas pemasaran (Leny Muniroh, dkk, 2017). Philip Kotler (2007:5) mendefinisikan bahwa, " Pemasaran adalah suatu proses sosial dan manajerial yang membuat individu dan kelompok memperoleh apa yang mereka butuhkan serta inginkan lewat penciptaan dan pertukaran timbal balik produk dan nilai dengan orang lain." Salah satu potensi yang dapat dimanfaatkan adalah potensi teknologi informasi yang berkembang pesat saat ini adalah media sosial. Media sosial memiliki potensi menghubungkan banyak orang dengan mudah dan gratis, sehingga media sosial saat ini menjadi trend dalam komunikasi pemasaran. Kaplan dan Haenlein dalam Leny Muniroh, dkk (2017), media sosial adalah sekelompok aplikasi berbasiskan internet yang dibangun berdasarkan kerangka pikiran ideology dan teknologi dari Web 2.0 dan memungkinkan terbentuknya kreasi pertukaran isi informasi dari pengguna internet. Web 2.0 adalah dasar terbentuknya sosial media (Carisson, 2010). Contoh-contoh media sosial yang berkembang saat ini adalah twitter, facebook, myspace, youtube, istagram, path, whatsapp, line, dll.

Membangun sebuah brand merupakan hal penting dalam era persaingan pasar global, baik skala usaha besar maupun skala kecil. Merek mewakili gambaran dan nilainilai yang ditanamkan oleh perusahaan. Merek mempengaruhi minat dan keputusan pembelian karena memudahkan konsumen ketika menghadapi banyak pilihan produk yang tersedia di pasaran. Kertajaya dalam H. Nugraha, dkk (2017) berpendapat hal terpenting dalam membangun sebuah merek (brand building) adalah terus menunjukkan nilai yang tinggi seperti kualitas hingga inovasi produk. Pengelolaan brand yang buruk akan menurunkan minat konsumen terhadap merek atau produk tersebut bahkan merek tersebut menghilang menghilang dari pasaran (Kotler, 2005).

Di masa pandemi covid 19 sekarang ini, banyak sector usaha yang mengalami gulung tikar, sehingga mengakibatkan bertambahnya jumlah pengangguran yang 
berdampak pada penurunan tingkat kesejahteraan dan perekonomian masyarakat. Keadaan seperti ini menuntut masyarakat untuk mencari peluang usaha dalam memenuhi kebutuhan hidupnya sehari-hari. Salah satunya adalah warga desa Heuleut Kecamatan Kadipaten, sebagian besar umumnya adalah sebagai petani yang bercocok tanam padi. Namun ada pula sebagian warga desa Heuleut menjadi pelaku UKM, yaitu sentra pelaku UKM di bidang industri pangan. Salah satu Potensi UKM dari Desa Heuleut yaitu usaha Home industry yang memproduksi tape ketan yang dijalankan oleh ibu Empat Patmawati yang beralamat di blok Sabtu Rt. 01/03 Desa Heuleut Kecamatan Kadipaten Kabupaten Majalengka. Usaha home industry tape ketan ini sudah cukup lama dijalankan sejak awal mulainya pada tahun 1997. Manajemen usaha yang dilakukan juga masih sederhana belum adanya perencanaan usaha yang baik dan produksi sesuai dengan permintaan konsumen. Sebagaimana yang dialami oleh usaha mikro lainnya, dalam melakukan produksi pun belum ada rutinitas dan tidak didasarkan pada standar kualitas tertentu. Meskipun tidak ada complain dari konsumen tetapi Ibu Empat Fatimah merasa kurang percaya diri untuk memasarkan secara lebih luas lagi.

Tape ketan terbuat dari beras ketan, ragi , air kukusan beras dan gula pasir. Pengembangan usaha yang dilakukan desa Heuleut memiliki beberapa kendala tentunya dapat dilihat dari aspek pemasaran masih dilakukan dengan cara berkeliling di Desa Heuleut. Selama ini proses produksi pembuatan tape ketan masih di lakukan secara tradisional dan manual (Home Industy). Selain permasalahan produksi, Ibu Empat juga mengalami keterbatasan pada masalah pengemasan yaitu belum adanya pengemasan (packaging) yang baik, dalam penyajian produk juga masih menggunakan alat yang sederhana dan belum ada brand atau merek untuk menengarai produk tersebut. Disamping pengemasan yang belum maksimal, masih terjadi persaingan antar penjual yang lain yang ada di sekitar rumahnya, serta terbatasnya bahan baku sehingga mengakibatkan terhentinya proses produksi. Wujud dari makanan ini dikemas dengan kotak plastik sederhana sehingga membuat kualitas produk ketan menjadi tidak tahan lama (Asnawi, dkk, 2017). Kualitas merupakan segala sesuatu yang mampu memenuhi keinginan atau kebutuhan konsumen (meeting the needs of customer). Definisi kualitas adalah total fitur dan karakteristik produk atau jasa yang mempengaruhi kemampuannya untuk memenuhi keinginan yang dinyatakan atau yang tersirat (Kotler, 2000). Hingga sekarang ini ibu Empat dalam menjual produknya tidak memakai label atau nama produk yang dapat memberikan brand dari tape ketan tersebut, sehingga kurang menarik. Maka dalam hal ini perlu adanya modernisasi untuk proses produksinya. Menurut Koentjaraningrat (1993), Modernisasi adalah usaha untuk hidup sesuai dengan zaman dan konstelasi dunia sekarang.

Dari hasil koordinasi dan pembahasan secara mendetail bersama Mitra UKM didapatkan beberapa permasalahan, antara lain :

1. Pemasaran masih dilakukan secara berkeliling di desa

Proses pemasaran yang dilakukan masih secara berkeliling di desa. Untuk memasarkan produknya memerlukan waktu yang cukup lama karena harus berkeliling menawarkannya, sehingga penjualan dan pemasaran hasil produksi tape ketan hanya kepada masyarakat sekitar desanya saja.

2. Pengemasan dan pelabelan tape ketan masih belum maksimal 
Pengemasan tape ketan masih belum maksimal yaitu masih menggunakan kemasan plastik yang sederhana, pembungkus tape ketan nya menggunakan daun jambu terkadang daun pisang, sehingga tape ketan yang dituangkan pada kemasan plastik tidak tersusun dengan baik dan terkadang sering adanya tumpahan air tape ketan nya. Selain itu belum adanya pelabelan pada kemasan nya yang mencerminkan brand dari sebuah produk, sehingga tidak memiliki daya tarik konsumen untuk membelinya dan mengenal produknya.

3. Keterbatasan bahan baku

Terbatasnya bahan baku untuk membuat tape ketan yaitu terkadang langkanya beras ketan yang tersedia di pasar atau suppley dari petani yang mungkin salah satunya diakibatkan karena harganya mahal. Selain itu bahan pembungkus tape ketannya yaitu kelangkaan daun jambu, sehingga terkadang diganti dengan daun pisang.

4. Proses produksi masih manual

Proses pembuatan tape ketan masih tradisional atau manual karena masih mempertimbangkan mesin yang harus digunakan untuk proses pembuatan tape ketan tersebut, sehingga masih perlu melakukan pelatihan modernisasi.

\section{Metode}

Berdasarkan permasalahan yang diuraikan diatas, dan sebagai solusi dari permasalahan tersebut, maka metode pelaksanaan kegiatan pengabdian kepada masyarakat yang akan dilakukan sebagaimana disajikan pada tabel di bawah ini :

Tabel 1. Metode Pelaksanaan dan Sasaran Kegiatan PKM

\begin{tabular}{|c|c|c|c|c|}
\hline Masalah & Solusi & $\begin{array}{c}\text { Program yang akan } \\
\text { dilaksanakan dan } \\
\text { Metode } \\
\text { Pelaksanaan } \\
\end{array}$ & $\begin{array}{c}\text { Target } \\
\text { (Indikator Kegiatan) }\end{array}$ & Sasaran \\
\hline $\begin{array}{l}\text { Pemasaran } \\
\text { masih } \\
\text { dilakukan } \\
\text { dengan cara } \\
\text { berkeliling di } \\
\text { Desa Heuleut } \\
\text { dan }\end{array}$ & $\begin{array}{l}\text { Sosialisasi } \\
\text { tentang } \\
\text { Pemasaran }\end{array}$ & $\begin{array}{l}\text { 1. Observasi, } \\
\text { Ceramah } \\
\text { 2. Fokus Group } \\
\text { Diskusi }\end{array}$ & $\begin{array}{l}\text { Pelaku UMKM di Desa } \\
\text { Heuleut (sebagai peserta) } \\
\text { yang dapat mengetahui dan } \\
\text { memahami tentang : } \\
\text { 1. Pentingnya metode } \\
\text { pemasaran produk } \\
\text { 2. Strategi pemasaran } \\
\text { 3. Pemasaran melalui } \\
\text { media sosial }\end{array}$ & $\begin{array}{l}\text { Para pelaku } \\
\text { UKM Tape } \\
\text { Ketan } \\
\text { Desa Heuleut } \\
\text { Kecamatan } \\
\text { Kadipaten }\end{array}$ \\
\hline $\begin{array}{l}\text { Pengemasan } \\
\text { tape ketan } \\
\text { masih belum } \\
\text { maksimal }\end{array}$ & $\begin{array}{l}\text { Edukasi } \\
\text { tentang } \\
\text { Packaging }\end{array}$ & $\begin{array}{l}\text { 1. Observasi, } \\
\text { Wawancara dan } \\
\text { Ceramah } \\
\text { 2. Fokus Group } \\
\text { Diskusi }\end{array}$ & $\begin{array}{l}\text { Pelaku UMKM di Desa } \\
\text { Heuleut (sebagai peserta) } \\
\text { yang dapat mengetahui dan } \\
\text { memahami tentang : } \\
\text { 1. Pentingnya packaging } \\
\text { produk } \\
\text { 2. Pentingnya labeling } \\
\text { produk } \\
\text { 3. Kegunaan packaging } \\
\text { produk }\end{array}$ & $\begin{array}{l}\text { Para pelaku } \\
\text { UKM Tape } \\
\text { ketan } \\
\text { Desa Heuleut } \\
\text { Kecamatan } \\
\text { Kadipaten }\end{array}$ \\
\hline $\begin{array}{l}\text { Terbatasnya } \\
\text { bahan baku }\end{array}$ & $\begin{array}{l}\text { Memberika } \\
\mathrm{n} \text { informasi } \\
\text { mengenai }\end{array}$ & $\begin{array}{l}\text { 1. Observasi, } \\
\text { Wawancara dan } \\
\text { Ceramah }\end{array}$ & $\begin{array}{l}\text { 1. Alternatif bahan baku } \\
\text { lain } \\
\text { 2. Mendapatkan chanel }\end{array}$ & $\begin{array}{l}\text { Para } \\
\text { UKM } \\
\text { Ketan }\end{array}$ \\
\hline
\end{tabular}




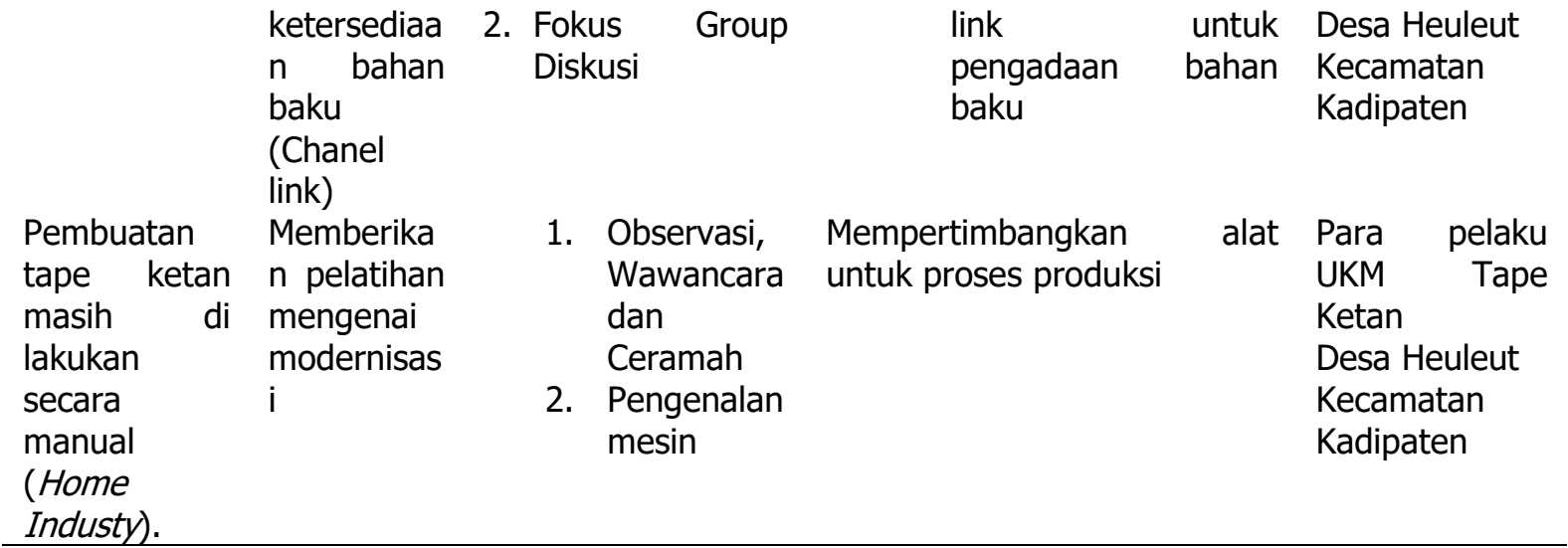

Tabel 2. Target, Luaran dan Indikator capaian

\begin{tabular}{lll}
\hline \multicolumn{2}{c}{ Target dan Luaran } & \multicolumn{1}{c}{ Indikator Capaian } \\
\hline Artikel Tersusun & Artikel \\
Jurnal $\quad$ Bernas & Universitas & Publish tahun 2020 \\
Majalengka & &
\end{tabular}

\section{Hasil dan Pembahasan}

Kegiatan pengabdian kepada masyarakat ini bekerja sama dengan Dinas UMKM Kabupaten Majalengka. Setelah dilaksanakan kegiatan tersebut, maka hasil yang diperoleh adalah sebagaimana dijabarkan sebagai berikut :

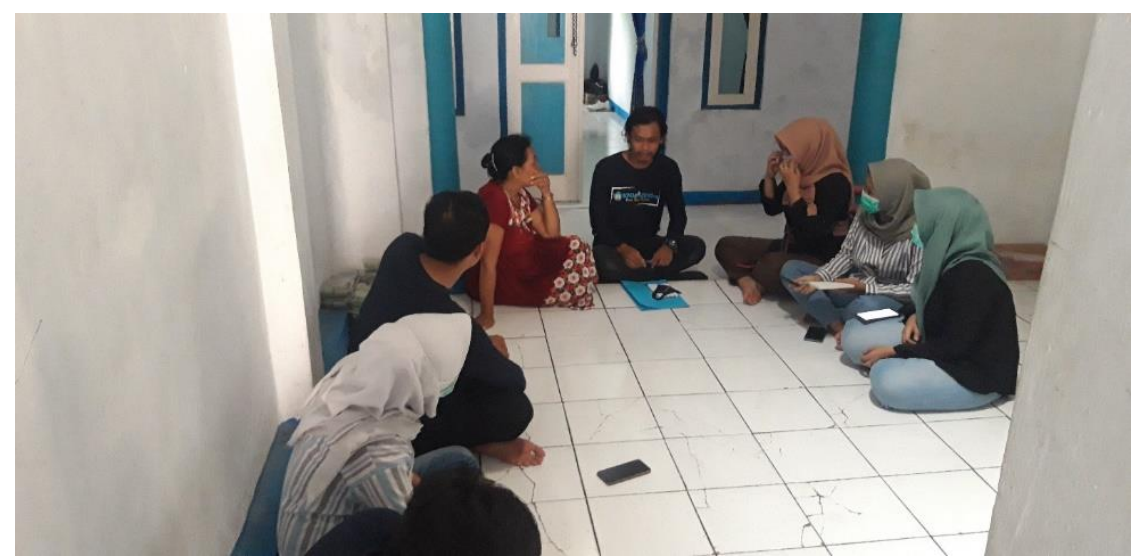

Gambar 1. Sosialisasi tentang Pemasaran

Pelaku UMKM Desa Heuleut mengikuti kegiatan sosialisasi dan edukasi pentingnya metode pemasaran sebuah produk. Pemasaran adalah sebuah metode memperkenalkan suatu produk kepada calon pembeli, dengan menginformasikan keunggulan produk, manfaat serta bahan baku produk tersebut. Metode pemasaran ini merupakan strategi dari penjualan bagi para pelaku usaha. Pemahaman akan pentingnya metode pemasaran produk tidak hanya diperuntukan bagi dirinya saja, tetapi disebarluaskan kepada para pelaku UMKM lainnya serta masyarakat secara umum. Setelah mengetahui dan memahami strategi pemasaran. Para pelaku UMKM menjadi lebih bersemangat untuk meningkatkan kualitas produk serta, melakukan inovasi produk dan menerapkan strategi pemasaran terkait produk tape ketan. Sehingga para pelaku UMKM tidak perlu merasa kebingungan dalam menjual tape ketan tersebut. Para pelaku UMKM desa Heuleut 
mengetahui bahwa pemasaran penting bagi pelaku usaha, sehingga para pelaku UMKM melakukan pelatihan terkait pemasaran di media social berupa WA, Facebook, Instagram. Dengan harapan produk bisa dikenal oleh masyarakat luas.

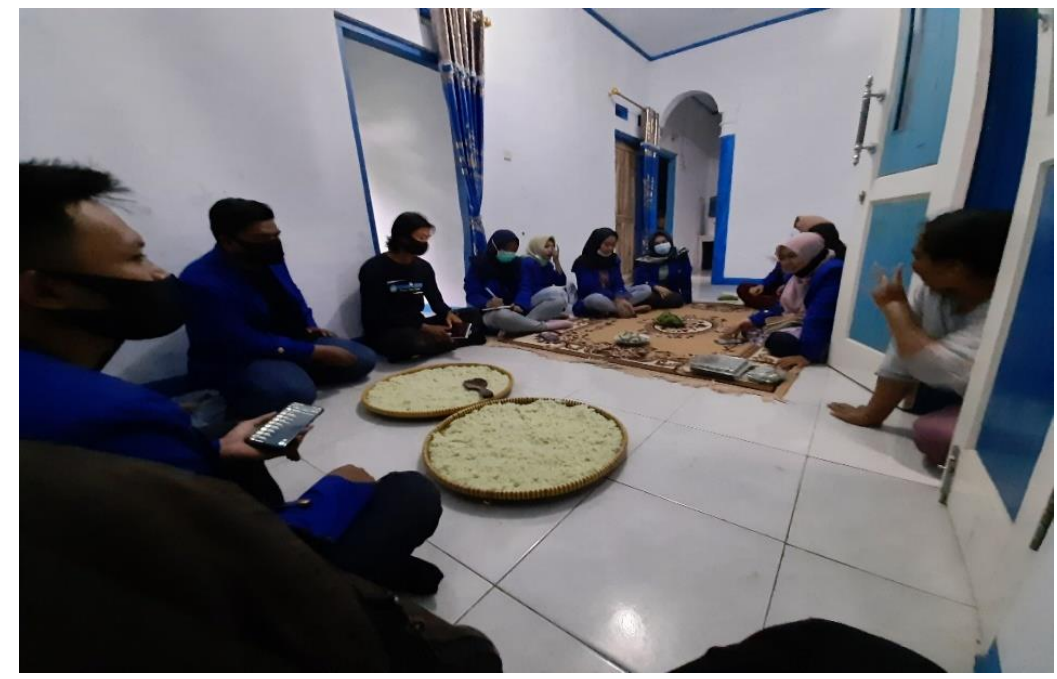

Gambar 2. Edukasi tentang packaging

Para pelaku UMKM desa Heuleut dapat mengetahui dan memahami pentingnya packaging produk. Packaging merupakan wadah untuk meningkatkan nilai dan fungsi sebuah produk dalam penjualan produk. Produk yang akan diperjual belikan bukan hanya produk yang memiliki nilai manfaat saja, melainkan produk yang memiliki kemasan unik, menarik, aman jika dikirim ke luar daerah. Para pelaku UMKM desa Heuleut memahami pentingnya packangingdarisebuah produk sebagainilai dalam meningkatkanpenjualan. Selain itu para pelaku UMKM desa Heuleut termotivasi untuk menggunakan labeling produk. Labeling merupakan identitas diri suatu produk, dengan labeling produk lebih mudah dikenal serta diingat oleh pembeli. Para pelaku UMKM desa Heuleut memahami kegunaan packaging, agar produk yang diperjual belikan lebih menarik, rapih, bersih serta aman jika produk tersebut dikrim ke luar daerah.

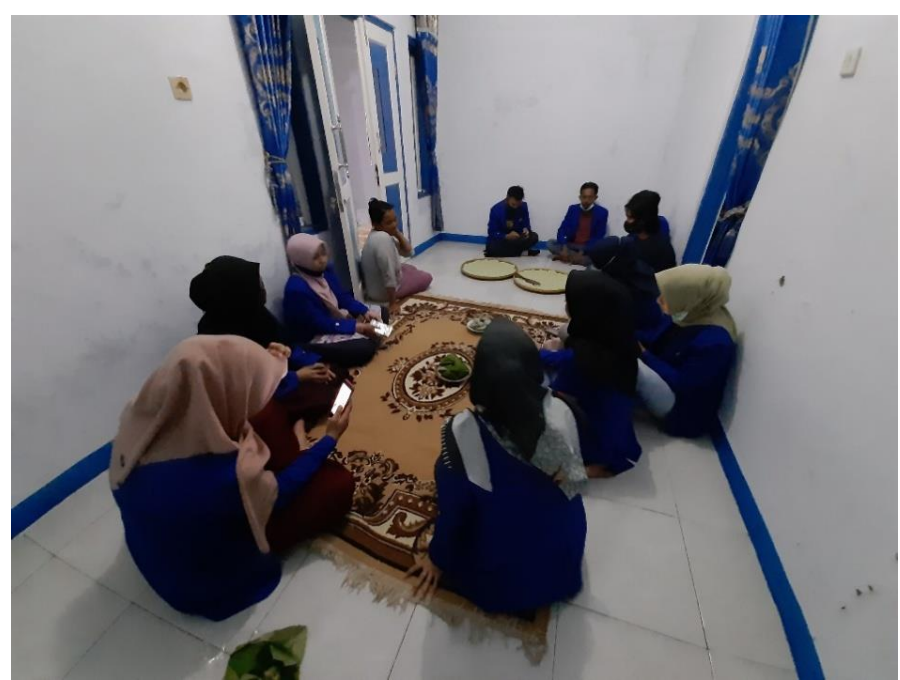

Gambar 3. Memberikan informasi mengenai ketersediaan bahan baku (Chanel link) 
Para pelaku UMKM Desa Heuleut, melakukan sharing dengan mahasiswa terkait bahan baku pembuatan tape ketan. Juga membahas ketersediaan bahan baku tape ketan yang terbatas, sedangkan pemintaan tape ketan terus mengalami kenaikan. Sehingga mahasiswa memberikan beberapa saran untuk bahan baku yang bisa digunakan dalam pembuatan tape ketan yaiu, ketan hitam atau beras ketan yang mudah diperoleh serta lebih ekonomis.

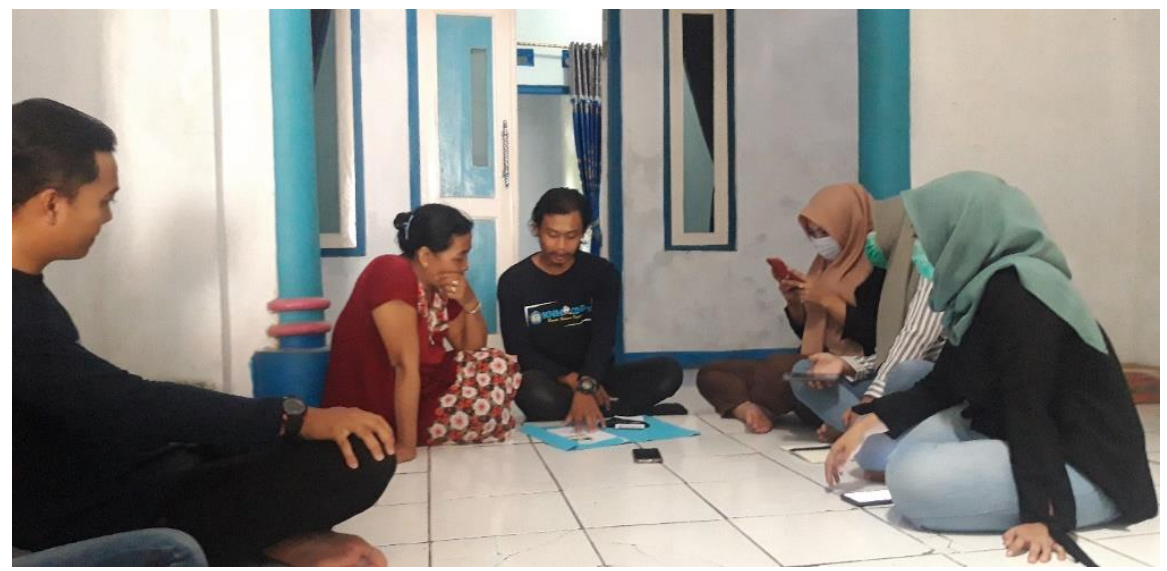

Gambar 4. Memberikan pelatihan mengenai modernisasi

Para pelaku UMKM memperoleh edukasi seputar modernisasi atau perubahan sosial kehidupan masyarakat yang lebih maju dan berkembang, sehingga terbentuk masyarakat modern. Modernisasi ditandai dengan adanya perubahan atas ilmu pengetahuan, teknologi, rasionalitas serta memiliki wawasan terbaru. Seperti halnya dalam UMKM ini masyarakat dituntun untuk mampu mengikuti perkembangan zaman, seperti proses pembuatan tape yang masih manual, penggunaan kemasan tradisional menggunakan daun jambu sehingga dari segi tampilan tidak menarik dan terbatasnya bahan baku untuk kemasan tape tersebut. Masyarakat memerlukan alternatif lain yang bisa digunakan untuk kemasan tape yang lebih hygienis dan aman.

\section{Kesimpulan}

Berdasarkan pelaksanaan dan hasil kegiatan, dapat disimpulkan bahwa : Pertama pelaku UMKM perlu mengetahui dan memahami pentingnya packaging suatu produk demi menjaga kualitas dan ketahanan produk tersebut. Kedua pelaku UMKM perlu mengetahui dan memahami pentingnya pemasaran serta strategi pemasaran yang akan digunakan agar para pelaku UMKM memiliki sasaran atas produk yang dihasilkan. Ketiga, pelaku UMKM perlu mengetahui dan memahami pentingnya packaging, labeling serta kegunaan packaging dengan tujuan produk yang akan diperjual belikan lebih menarik minat pembeli karena pengemasannya yang unik serta aman jika produk tersebut di kirim ke luar daerah.

Berdasarkan kesimpulan diatas, ada beberapa saran yang dapat dikemukakan antara lain sebagai berikut :

1. Bagi pelaku UMKM, agar melakukan inovasi baik dari segi produk, pengemasan maupun metode pemasaran sehingga produk tersebut mampu bersaing dan bertahan di masa era adaptasi kebiasaan baru covid 19. 
2. Bagi Universitas Majalengka, pendampingan pelaku UMKM Desa Heuleut harus dapat ditindaklanjuti. Upaya ini dapat dilakuan dengan membentuk Inkubator Bisnis Universitas Majalengka yang dapat memberikan bimbingan dan konseling bagi pengembangan UMKM secara umum.

\section{Daftar Pustaka}

A.Asnawi, Ilham Maulana Saud, Wiratmanto. (2017). Peningkatan Mutu Produk dan Pemasaran Olahan Ikan. Berdikari, Jurnal Inovasi Dan Penerapan Ipteks. Vol. 5 No. 1

Andreas, Kaplan M., Haenlein Michael (2010). "Users of the world, unite! The challenges and opportunities of social media". Business Horizons 53 (1). p. 61.

H. Nugraha, F. Ariyanti, D. Wanto. (2017). Penerapan Branding Pada UKM Makanan Ringan Di Kabupaten Jepara. Jurnal Administrasi Bisnis. eISSN 2548-4923, pISSN 2252-3294. Vol. 6 no. 1, pp. 16-23

Hermawan Kartajaya. (2004). Positioning, Diferensiasi, dan Brand. Jakarta: PT. Gramedia Pustaka Utama.

Kotler, Philip (2000). Prinsip - Prinsip Pemasaran Manajemen, Jakarta : Prenhalindo.

Kotler, Philip dan Keller, (2007), Manajemen Pemasaran, Jilid I, Edisi Kedua belas, PT. Indeks, Jakarta.

Kotler, Philip. (2005). Manajemen Pemasaran. Jilid 1 dan 2. Jakarta : PT Indeks Kelompok Gramedia.

Leny Muniroh, Diah Yudhawati, Hurriyaturrohman. (2017). Pelatihan Pemasaran secara Online pada UMKM Tas Di Bojong Rangkas Ciampea Kabupaten Bogor. 2017. Prosiding LPPM UIKA BOGOR [S.I], p. 75-82. ISSN 2477-4014.

Muhamad Firdaus, Ahmad Habib, Sugiono. (2018). Peningkatan Kualitas dan Kapasitas Produksi Serta Pemasaran Produk UKM (Studi Kasus UKM Keripik Pisang Dan Ketela Di Trawas Mojokerto). Seminar Nasional Hasil Penelitian dan Pengabdian Masyarakat. ISBN:978-602-53170-2-6. Vol. 1 No. 1

Undang-Undang Nomor 6 Tahun 2014 tentang Desa

Universitas Majalengka, (2019). Keputusan Rektor Universitas Majalengka Nomor : 137/KEP/UNMA/IX/2019 Tentang Pengesahan Panduan Hibah Penelitian dan Pengabddian Kepada Masyarakat Universitas Majalengka. 